\title{
KUALITAS FISIK DAN KIMIA DEDAK PADI YANG DISIMPAN MENGGUNAKAN TEPUNG KULIT MANGGIS(Garcinia mangostana linn) PADA LEVEL BERBEDA
}

\author{
Tabita N. Ralahalu ${ }^{1 *}$, S. Fredriksz ${ }^{1}$, S. Tipka ${ }^{2}$ \\ ${ }^{1}$ Jurusan Peternakan, Fakultas Pertanian, Universitas Pattimura \\ Jl. Ir.M. Putuhena, Kampus Poka, Ambon 97233 \\ ${ }^{2}$ Alumni Jurusan Peternakan, Fakultas Pertanian, Universitas Pattimura \\ ${ }^{*}$ Email : ipopralahalu@gmail.com
}

\begin{abstract}
ABSTRAK
Masalah dalam pemanfaatan dedak padi sebagai pakan ternak, yaitu stabilitasnya yang rendah akibat ketengikan hidrolisis dan ketengikan oksidasi. Selain itu cepat menjadi menggumpal dan mendatangkan serangga khususnya kutu. Penelitian yang dilakukan bertujuan untuk mengetahui taraf penggunaan tepung kulit manggis dalam penyimpanan dedak padi selama satu bulan terhadap kualitas fisik dan kimia dedak padi. Penelitian dilaksanakan di Laboratorium Nutrisi dan Makanan Ternak Jurusan Peternakan Fakultas Pertanian Universitas Pattimura, Ambon. Bahan yang digunakan dalam penelitian ini adalah dedak padi komersial dari Gemba dan kulit manggis. Peralatan yang digunakan adalah karung plastik, timbangan kapasitas $5 \mathrm{~kg}$, timbangan digital, blender, alat pengukur suhu dan kelembaban. Penelitian yang dilakukan menggunakan rancangan acak lengkap (RAL), 4 x 4. Peubah yang diamati meliputi berat, warna, bau, kadar air, protein kasar, lemak, dan bilangan peroksida. Uji lanjut yang digunakan jika perlakuan menunjukkan perbedaan nyata adalah uji Duncan. Perlakuan yang dicobakan adalah DKM0 (Dedak padi tanpa kulit manggis), DKM1 (Dedak padi dengan pemberian $5 \%$ tepung kulit manggis), DKM2 (Dedak padi dengan pemberian 7,5\% tepung kulit manggis) dan DKM3 (Dedak padi dengan pemberian 12,5\% tepung kulit manggis). Penggunaan tepung kulit manggis $5 \%$ dapat menurunkan angka bilangan peroksida sampai mencapai angka 7,95 meq/kg, sedangkan pada taraf $10 \%$ dapat menekan bau sampai menjadi agak tengik. Penggunaan tepung kulit manggis $15 \%$ tidak signifikan terhadap warna, jamur, kadar air, protein kasar, lemak dan bilangan peroksida dedak padi.
\end{abstract}

Kata kunci: dedak padi, kulit manggis, penyimpanan, kualitas fisik, kualitas kimia

\section{PHYSICAL AND CHEMICAL QUALITY OF RICE BRAN STORED USING DIFFERENT LEVEL OF MANGOSTEEN PEEL FLOUR (Garcinia mangostana linn)}

\begin{abstract}
The problem in using rice bran as animal feed is its low stability due to rancidity of hydrolysis and rancidity of oxidation. In addition, it quickly becomes clumpy and brings in insects, especially lice. The objective of this research was to determine the level of use of mangosteen peel flour in rice bran storage for one month on the physical and chemical qualities of rice bran. The research was conducted at the Laboratory of Animal Nutrition and Forage, Department of Animal Husbandry, Faculty of Agriculture, Pattimura University, Ambon. The materials used are rice bran from Gemba and mangosteen peel. The equipment used is a plastic sack with a size of $5 \mathrm{~kg}$, a digital scale, a blender, a temperature and humidity measuring device. The research was conducted using a completely randomized design (CRD), 4 x 4. The observed variables included weight, color, odor, moisture content, crude protein, fat, and peroxide number. The follow-up test used if the treatments show significant differences is the Duncan test. The treatments tested were DKM0 $=$ rice bran without mangosteen peel flour; DKM1 = rice bran with 5\% mangosteen peel flour; DKM2 = rice bran with 7.5\% mangosteen peel flour; DKM3 = Rice bran with $12.5 \%$ mangosteen peel flour. The peroxide value of $7.95 \mathrm{meq} / \mathrm{kg}$ is achieved when using 5\% mangosteen peel flour, while at the $10 \%$ level it can suppress the smell until it becomes slightly rancid. The use of $15 \%$ mangosteen peel flour was not significant for color, fungus, protein moisture, fat and peroxide numbers.
\end{abstract}

Key words: Rice bran, mangosteen peel, storage, physical quality, chemical quality 


\section{PENDAHULUAN}

Dedak padi merupakan limbah pertanian dan penting dalam usaha peternakan sebagai bahan makanan ternak. Hal ini karena masyarakat Indonesia memanfaatkan padi sebagai salah satu sumber bahan makanan pokok, di sisi lain Indonesia adalah negara berswasembada beras dan dedaknya tidak dikonsumsi oleh manusia (Zulbardi dkk., 2001). Produksi padi di Indonesia pada tahun 2011, menduduki peringkat ketiga terbesar di dunia setelah Cina dan India. Produksi tersebut dapat menghasilkan dedak padi mencapai 67,3 juta ton, jika dedak padi yang dihasilkan sebagai hasil samping penggilingan padi dapat mencapai $8-10 \%$ (Herodian, 2007). Hasil ini memperlihatkan potensi ketersediaan dedak padi di Indonesia sangat tinggi. Selain itu ditinjau dari kadar nutrient dedak padi, masih memiliki nutrient yang dapat digunakan sebagai pakan, dan tidak kompetitif dengan kebutuhan manusia serta mempunyai harga yang murah (Astawan \& Febrinda, 2010).

Ketersediaan jerami padi dan dedak padi tersedia hampir sepanjang tahun sehingga dapat digunakan sebagai sumber pakan ternak, khususnya pada musim kemarau. Untuk menyediakan pakan ternak secara kontinyu, diperlukan suatu teknologi pengawetan sehingga pada saat bahan pakan melimpah dapat disimpan tanpa mengurangi kandungan nutriennya (Mulijanti dkk., 2014). Keterbatasan penggunaan dedak padi sebagai campuran pakan ternak terutama pada ternak seperti halnya pada unggas adalah kandungan proteinnya yang rendah, mudah tengik, dan adanya asam fitat yang mampu mengikat mineral $\mathrm{Ca}$ dan $\mathrm{P}$, serta mengikat protein menjadi fitatprotein kompleks yang berdampak pada menurunnya manfaat serta kecernaannya (Wibawa dkk., 2015).

Ketersediaan dedak padi sangat terkait dengan waktu atau musim panen padi, sehingga persediaan stok oleh peternak pun dalam jumlah yang banyak. Namun kelemahan dari dedak padi adalah tidak dapat disimpan dalam jangka waktu yang lama, karena memiliki lemak yang tinggi, yakni $12,15 \%$, sehingga mudah menjadi rusak. Hal ini jelas menyatakan, bahwa permasalahan dalam pemanfaatan dedak padi sebagai pakan ternak adalah stabilitasnya yang rendah akibat ketengikan hidrolisis dan ketengikan oksidasi. Selain itu cepat menjadi menggumpal dan mendatangkan serangga khususnya kutu (Astawan \& Febrinda, 2010). Berdasarkan sifat yang dimiliki dedak padi, maka perlu diupayakan suatu cara untuk dapat mengatasi masalah tersebut.

Banyak cara telah diteliti, namun pemanfaatan bahan alami belum banyak diteliti. Oleh karena itu pada kesempatan ini akan diteliti penggunaan kulit buah manggis sebagai komponen antioksidan yang terdapat di alam secara melimpah. Kulit buah manggis (Garcinia mangostana L.) mengandung senyawa yang memiliki aktivitas farmakologi dan antioksidan. Senyawa tersebut diantaranya flavonoid, tanin dan xanton (Nakatani et al., 2002), akan tetapi menurut Roza dkk. (2017) sifat antioksidan radikal bebas kulit manggis akan menurun sejalan dengan lama penyimpanan. Untuk hasil panen yang tidak terjual dilakukan penyimpanan seadanya. Hal ini membuat petani manggis tidak dapat meningkatkan pendapatannya, untuk itu perlu dicarikan solusi sehingga buah dengan kualitas rendah itu dapat dimanfaatkan untuk keperluan lain. Dalam penyimpanan dedak padi, penggunaan kulit buah manggis, disebabkan kulit buah manggis mempunyai banyak manfaat, diantaranya dapat dijadikan sebagai anti inflamasi, anti tumor, antioksidan dan anti bakteri.

Penelitian yang dilakukan bertujuan ini untuk mengetahui taraf penggunaan tepung kulit manggis dalam penyimpanan dedak padi selama satu bulan terhadap kualitas fisik dan kimia dedak padi. Hipotesis yang dapat dikemukakan adalah bahwa taraf penggunaan kulit manggis $15 \%$ menghasilkan kualitas fisik dan kimia dedak padi yang lebih baik.

\section{MATERI DAN METODE}

Bahan yang digunakan dalam penelitian ini adalah dedak padi yang diperoleh dari Desa Gemba Kabupaten Maluku Tengah dan kulit manggis yang diperoleh dari pasar Mardika kota Ambon. Peralatan yang digunakan adalah karung plastik berukuran sesuai berat bahan, timbangan kapasitas $5 \mathrm{~kg}$, timbangan digital, blender, alat pengukur suhu dan kelembaban. Penelitian ini berlangsung selama tiga (3) bulan, dilaksanakan di Laboratorium Nutrisi dan Makanan Ternak Jurusan Peternakan Fakultas Pertanian Universitas Pattimura, Ambon.

Prosedur penelitian yang dilakukan pertama kali adalah membuat serbuk kulit manggis, tahapannya adalah kulit buah manggis yang masih segar, diambil bagian dalamnya yang lembek ; kemudian diiris tipis dan dijemur dibawah matahari sampai kering ; setelah itu diblender sampai menjadi tepung. Langkah selanjutnya adalah persiapan perlakuan, dengan tahapannya adalah (1) dedak padi ditimbang untuk semua perlakuan sebanyak 250 gram ; (2) setelah itu dicampurkan dengan tepung kulit manggis sesuai dengan perlakuan ; (3) kemudian dimasukkan dalam karung, dijahit mulut karungnya dan diletakkan di atas palet selama 1 bulan ; dan (4) karung masing-masing perlakuan dibuka untuk dilakukan pengamatan pada skala laboratorium sesuai peubah peneltian yang diamati.

Penelitian yang dilakukan adalah penelitian eksperimen dengan menggunakan rancangan acak lengkap (RAL), 4 perlakuan dengan 4 ulangan pada tiap perlakuan. Peubah yang diamati adalah kualitas fisik dedak padi (meliputi berat, warna, aroma atau bau, dan keberadaan kutu), dan kualitas kimia atau kadar nutrient dedak padi (meliputi kadar air, protein kasar, lemak, dan bilangan peroksida). Uji lanjut yang digunakan jika perlakuan menunjukkan perbedaan 
nyata adalah uji DMRT (Duncan Multiple Range Test). Adapun perlakuan yang dicobakan adalah sebagai berikut DKM0 (dedak padi dengan pemberian tepung kulit manggis $0 \%$ ), DKM1 (dedak padi dengan pemberian $5 \%$ tepung kulit manggis), DKM2 (dedak padi dengan pemberian 7,5\% tepung kulit manggis), dan DKM3 (dedak padi dengan pemberian 12,5\% tepung kulit manggis). Model matematik percobaan rancangan acak lengkap (RAL) dalam penelitian ini menurut Gaspersz (1995) adalah:
Keterangan :

$$
\mathrm{Y}_{\mathrm{ij}}=\mu+\tau_{\mathrm{i}}+\varepsilon_{\mathrm{ij}}
$$

$\mathrm{Y}_{\mathrm{ij}}$ : Nilai pengamatan (kualitas fisik atau kualitas kimia) dedak padi yang memperoleh perlakuan ke-i dan ulangan ke-j ;

M : Nilai tengah pengamatan ;

$\tau_{\mathrm{i}} \quad$ : Pengaruh perlakuan ke-i, dengan $\mathrm{i}=1,2,3,4$;

$\varepsilon_{\mathrm{ij}}$ : Pengaruh galat percobaan dari pengamatan yang memperoleh perlakuan ke-i dan ulangan ke-j, dengan $\mathrm{j}=1,2,3,4$.

Tabel 1. Penggunaan Tepung Kulit Manggis terhadap Rata-rata Berat Akhir Dedak Padi

\begin{tabular}{ccc}
\hline Perlakuan & Berat Awal (gram) & Berat Akhir (gram) \\
\hline DKM0 & 250 dedak padi +0 tepung kulit manggis $=250$ & 242,5 \\
DKM1 & 250 dedak padi $+12,5$ tepung kulit manggis $=$ & 254,5 \\
DKM2 & 262,5 & 266,25 \\
DKM3 & 250 dedak padi +25 tepung kulit manggis $=275$ & 282,75 \\
& 250 dedak padi $+37,5$ tepung kulit manggis $=$ & 287,5 \\
\hline
\end{tabular}

Ket: DKM0 $=$ dedak padi tanpa kulit manggis; DKM1 = dedak padi $+5 \%$ tepung kulit manggis; DKM2 = dedak padi $+10 \%$ tepung kulit manggis; DKM3 = dedak padi $+15 \%$ tepung kulit manggis.

\section{HASIL DAN PEMBAHASAN}

\section{Berat Dedak Padi}

Penelitian penyimpanan dedak padi menggunakan tepung kulit manggis menghasilkan berat akhir dedak padi yang berbeda untuk semua perlakuan. Hasil tersebut dapat dilihat pada Tabel 1.

Hasil analisis statistik menunjukkan pengaruh perlakuan tidak signifikan $(\mathrm{P}>0,05)$ terhadap berat akhir dedak padi yang disimpan selama satu bulan. Hal ini dapat dipahami karena berat akhir dari perlakuan memperlihatkan perbedaan nilai yang tidak berarti. Hasil ini memperlihatkan tepung kulit manggis pada berbagai tingkat penggunaan dalam dedak padi yang disimpan selama satu bulan memberikan pengaruh yang masih rendah sehingga secara statistik belum signifikan. Namun berdasarkan hasil pengamatan selama penelitian, penurunan yang terjadi dapat disebabkan oleh adanya kutu selama penyimpanan. Penggunaan tepung kulit manggis pada tingkat penggunaan sampai $15 \%$ mampu mengurangi jumlah kutu dalam dedak padi, yaitu sebanyak 40 ekor atau $21,57 \%$ dari perlakuan DKM0, 28,95\% dari perlakuan DKM1, dan 44,44 \% dari DKM2. Kutu yang terdapat dalam dedak padi bertumbuh dan berkembang. Oleh karena itu membutuhkan suplai nutrien dan untuk kebutuhan tersebut diperoleh dari dedak padi. Kondisi ini sesuai dengan pendapat Nurfitriani (2014), bahwa perubahan fisik yang ditimbulkan serangga di antaranya adalah kehilangan bobot atau jumlah bahan.

\section{Warna Dedak Padi}

Warna dedak padi pada penelitian ini dianalisis secara visual. Hasil pengamatan memperlihatkan adanya perubahan warna pada dedak padi, baik dedak padi tanpa menggunakan tepung kulit manggis maupun dedak padi yang diberi tambahan tepung kulit manggis pada persentase penggunaan yang berbeda. Hasil pengamatan warna dedak padi dapat dilihat pada Tabel 2.

Tabel 2. Penggunaan Tepung Kulit Manggis Terhadap Warna Dedak Padi

\begin{tabular}{ccc}
\hline Perlakuan & Sebelum Penyimpanan & Akhir Penyimpanan \\
\hline DKM0 & Coklat & Coklat pucat \\
DKM1 & Coklat muda & Coklat agak muda \\
DKM2 & Coklat agak tua & Coklat \\
DKM3 & Coklat tua & Coklat agak tua \\
\hline
\end{tabular}

Ket: DKM0 = dedak padi tanpa kulit manggis; DKM1 = dedak padi $+5 \%$ tepung kulit manggis; DKM2 = dedak padi $+10 \%$ tepung kulit manggis; DKM3 $=$ dedak padi $+15 \%$ tepung kulit manggis.

Perubahan warna pakan yang terjadi selama penyimpanan menggambarkan penggunaan tepung kulit manggis sampai $15 \%$ belum dapat mempertahankan warna dedak padi. Winarno dkk. (1997) menyatakan bahwa perubahan warna pada pakan disebabkan oleh meningkatnya kadar air dalam pakan. Kadar air dedak padi yang menggunakan tepung kulit manggis selama penyimpanan mempunyai variasi yang tidak jauh berbeda, yaitu $11,46 \% ; 12,15$ 
$\% ; 11,49 \%$, dan $12,35 \%$ masing-masing untuk perlakuan DKM0, DKM1, DKM2, dan DKM3.

Besaran nilai kadar air pada perlakuan DKM1 dan DKM2 hampir sama dengan besaran nilai kadar air pada pakan komersial babi yang disimpan selama satu bulan, yaitu 12,03\%. Pada kondisi tersebut pakan komersial babi yang disimpan selama satu bulan belum mengalami perubahan warna, jika dibandingkan dengan penyimpanan dedak selama periode yang sama. Dengan demikian terjadinya perubahan warna pada dedak padi dalam penelitian ini lebih disebabkan oleh jenis pakan bukan oleh kadar air. Hal ini terlihat pada pakan babi komersial yang disimpan. Pakan babi komersial merupakan kombinasi dari beberapa jenis bahan pakan dan berbentuk pellet, sedangkan dedak padi yang digunakan dalam penelitian ini berbentuk mash. Kondisi ini sama seperti yang dinyatakan oleh Winarno (1997), yaitu salah satu faktor yang berpengaruh terhadap pakan selama penyimpanan adalah jenis pakan. Demikian juga oleh Prasetyo (2006), menyatakan ransum bentuk pellet dan crumble masih dapat digunakan oleh ternak dengan lama penyimpanan kurang lebih satu bulan sedangkan bentuk mash hanya tahan selama kurang lebih 2 minggu. Selain bentuk fisik pakan, faktor lain yang menyebabkan terjadinya perubahan warna adalah penyimpanan yang terlalu lama (Yokotsuka, 1986).

\section{Aroma Dedak Padi}

Penggunaan tepung kulit manggis pada taraf yang berbeda dalam dedak padi dan disimpan selama satu bulan menghasilkan aroma dedak padi yang berbeda. Hasil penelitian memperlihatkan aroma dedak padi pada semua perlakuan pada akhir penyimpanan mengalami perubahan aroma selama penyimpanan satu bulan.

Tabel 3. Penggunaan Tepung Kulit Manggis Terhadap Aroma Dedak Padi

\begin{tabular}{ccc}
\hline Perlakuan & Sebelum Penyimpanan & Akhir Penyimpanan \\
\hline DKM0 & Khas dedak padi & Sangat tengik \\
DKM1 & Khas dedak padi & tengik \\
DKM2 & Khas dedak padi & Agak Tengik \\
DKM3 & Khas dedak padi & Tidak Tengik \\
\hline
\end{tabular}

Ket: DKM0 = dedak padi tanpa kulit manggis; DKM1 = dedak padi $+5 \%$ tepung kulit manggis; DKM2 = dedak padi $+10 \%$ tepung kulit manggis; DKM3 $=$ dedak padi $+15 \%$ tepung kulit manggis.

Aroma perlakuan DKM0 adalah sangat tengik., DKM1 tengik, DKM2 agak tengik, demikian pula DKM3 tidak tengik seperti terlihat pada Tabel 3. Menurunnya aroma dedak padi terlihat mengikuti persentase penggunan tepung kulit manggis. Penggunaan tepung kulit manggis sampai $15 \%$ dalam dedak padi dapat mengurangi aroma dedak padi dari sangat tengik (DKM0) menjadi tidak tengik (DKM3). Hasil ini menggambarkan penggunaan tepung kulit manggis mampu memperlambat terjadinya proses ketengikan seperti yang terjadi pada perlakuan DKM3. Diduga antioksidan bereaksi dengan oksidan sehingga mengurangi kapasitas oksidan untuk menimbulkan kerusakan. Rohdiana (2001), menyatakan bahwa antioksidan alami seperti senyawa fenolik maupun sintesis mampu menghambat oksidasi lipid, mencegah kerusakan, perubahan komponen organik dalam bahan pakan sehingga memperpanjang umur simpan.
Mekanisme kerja antioksidan alami (senyawa fenolik) dalam menghambat oksidasi atau menghentikan reaksi berantai pada radikal bebas dari lemak yang teroksidasi dapat disebabkan oleh 4 mekanisme reaksi yaitu a) pelepasan hidrogen dari antiokasidan, b) pelepasan elektron dari antioksidan, 3) adisi lemak ke dalam cincin aromatik pada antioksidan, dan 4) pembentukan senyawa kompleks antara lemak dan cincin aromatik dari antioksidan (Puspitasari dkk., 2016).

\section{Keberadaan Kutu}

Penyimpanan dedak padi dengan menggunakan tepung kulit manggis yang disimpan selama satu bulan menghasilkan kutu pada semua perlakuan dengan jumlah yang bervariasi. Jumlah kutu rata-rata pada perlakuan DKM0 sebanyak 69 ekor, DKM1 56,33 ekor, DKM2 54,66 ekor, dan DKM3 sebanyak 40 ekor (Tabel 4).

Tabel 4. Penggunaan Tepung Kulit Manggis terhadap Rataan Jumlah Kutu Dedak Padi

\begin{tabular}{ccc}
\hline Perlakuan & Sebelum Penyimpanan & Sesudah Penyimpanan \\
\hline DKM0 & Tidak ada & 69 ekor \\
DKM1 & Tidak ada & 56,33 ekor \\
DKM2 & Tidak ada & 54,66 ekor \\
DKM3 & Tidak ada & 40 ekor \\
\hline
\end{tabular}

Ket: DKM0 = dedak padi tanpa kulit manggis; DKM1 = dedak padi + 5\% tepung kulit manggis; DKM2 = dedak padi $+10 \%$ tepung kulit manggis; DKM3 $=$ dedak padi $+15 \%$ tepung kulit manggis.

Hasil ini memperlihatkan jumlah kutu yang tertinggi pada perlakuan DKM0 dan terendah pada DKM3. Jumlah kutu yang lebih tinggi pada perlakuan
DKM0 disebabkan pada perlakuan tersebut tidak diberikan tepung kulit manggis dan dedak padi yang digunakan masih dalam keadaan segar. Hal ini sesuai 
dengan pendapat Ramahariah dkk. (2014), bahwa pertumbuhan serangga cenderung lebih besar selama penyimpanan pada dedak padi yang masih segar. Di sisi lain penggunaan tepung kulit manggis $15 \%$ dapat menekan jumlah kutu 42,03 \% dari perlakuan DKM0, 28,99 \% dari DKM1, dan 26,82 \% dari perlakuan DKM2. Jumlah kutu yang sedikit pada perlakuan DKM3 kemungkinan disebabkan alfa mangostin, salah satu senyawa turunan dari senyawa Xanton yang dapat berfungsi sebagai biolarvasida. Gugus fungsi dari alfa mangostin berikatan dengan sisi aktif enzim pencernaan sehingga dapat memberi efek toksik pada larva Aedes Aegypti (Syahputra, 2015). Pernyataan ini memberi dugaan bahwa jumlah kutu pada perlakuan DKM3 yang rendah kemungkinan disebabkan kutu pada dedak padi mendapat efek toksik sehingga tidak dapat bertahan hidup.

\section{Kualitas Kimia Dedak Padi}

Kadar air dedak padi yang disimpan menggunakan tepung kulit manggis pada taraf yang berbeda selama satu bulan tidak signifikan $(\mathrm{P}>0,05)$.
Penggunaan tepung kulit manggis terhadap kadar air dedak padi dapat dilihat pada Tabel 5. Penggunaan tepung kulit manggis pada taraf yang berbeda dalam penyimpanan dedak padi memperlihatkan kadar air yang fluktuatif. Kadar air bahan selama penyimpanan dipengaruhi oleh suhu dan kelembaban dalam ruang penyimpanan. Selama penelitian berlangsung suhu dan kelembaban berfluktuatif, yaitu rataan suhu dan kelembaban pada minggu pertama $28,5^{\circ} \mathrm{C}$ dan 84,75 $\%$, minggu kedua $30,5{ }^{\circ} \mathrm{C}$ dan $78 \%$, minggu ketiga $31,25^{\circ} \mathrm{C}$ dan $70,25 \%$, dan minggu keempat $29,75^{\circ} \mathrm{C}$ dan $75,5 \%$. Jika dikaitkan dengan suhu yang diperlukan selama penyimpanan bahan, maka suhu pada minggu kedua dan ketiga sudah sesuai dengan yang disarankan yaitu berkisar antara $30-34{ }^{\circ} \mathrm{C}$. Sebaliknya kelembaban yang disarankan oleh SNI tidak lebih dari $70 \%$. Fluktuatifnya kelembaban berpengaruh terhadap kadar air bahan walaupun tidak signifikan. Kondisi ini didukung oleh pendapat Retnani dkk. (2008), bahwa absorbs uap air dari udara ke dalam ransum dipengaruhi oleh kelembaban udara dalam ruang selama penyimpanan.

Tabel 5. Penggunaan Tepung Kulit Manggis terhadap Kadar Air, Kadar Lemak, Kadar Protein, dan Bilangan Peroksida Dedak Padi

\begin{tabular}{ccccc}
\hline Perlakuan & Kadar Air (\%) & Kadar Lemak (\%) & Kadar Protein (\%) & $\begin{array}{c}\text { Bilangan } \\
\text { Peroksida (meq/kg) }\end{array}$ \\
\hline DKM0 & $11,46^{\mathrm{a}}$ & $6,22^{\mathrm{a}}$ & $9,04^{\mathrm{a}}$ & $9,28^{\mathrm{a}}$ \\
DKM1 & $12,15^{\mathrm{a}}$ & $3,54^{\mathrm{a}}$ & $8,98^{\mathrm{a}}$ & $7,95^{\mathrm{b}}$ \\
DKM2 & $11,49^{\mathrm{a}}$ & $4,05^{\mathrm{a}}$ & $9,15^{\mathrm{a}}$ & $8,37^{\mathrm{b}}$ \\
DKM3 & $12,35^{\mathrm{a}}$ & $4,82^{\mathrm{a}}$ & $9,08^{\mathrm{a}}$ & $8,38^{\mathrm{b}}$ \\
\hline
\end{tabular}

Ket: Superskrip yang berbeda pada kolom yang sama menunjukkan perbedaan yang signifikan $(\mathrm{P}<0,05)$.

DKM0 $=$ dedak padi tanpa kulit manggis; DKM1 = dedak padi $+5 \%$ tepung kulit manggis;

DKM2 = dedak padi $+10 \%$ tepung kulit manggis; DKM3 = dedak padi $+15 \%$ tepung kulit manggis.

Penggunaan tepung kulit manggis pada taraf yang berbeda dalam dedak padi yang disimpan selama satu bulan menghasilkan kadar lemak yang berbeda (Tabel 5). Hasil analisis statistik menunjukkan penggunaan tepung kulit manggis dalam penyimpanan dedak padi tidak signifikan $(\mathrm{P}>0,05)$ terhadap kadar lemak. Hasil penelitian ini memperlihatkan persentase penurunan kadar lemak tertinggi terjadi pada perlakuan DKM1 dan terendah pada DKM3. Terjadinya penurunan kadar lemak dedak padi diduga disebabkan selama penyimpanan terjadi perombak lemak menjadi asam lemak dan gliserol. Pendapat ini didukung oleh Ketaren (2008) yang menyatakan bahwa sebagian besar asam lemak tidak jenuh akan rusak dengan bertambahnya umur simpan. Umur simpan dedak padi pada penelitian ini mempunyai waktu yang sama, yaitu satu bulan sehingga diduga pernyataan Ketaren (2008) dalam hal ini rusaknya asam lemak tidak jenuh dalam dedak padi dianggap sama. Terjadinya penurunan kadar lemak dedak padi disebabkan adanya kandungan antioksidan di dalam tepung kulit manggis. Pernyataan ini didukung oleh Rohdiana (2001), bahwa adanya antioksidan alami seperti senyawa fenolik maupun sintesis mampu menghambat terjadinya oksidasi sehingga memperpanjang masa simpan. Sedangkan menurut Dungir dkk. (2012) bahwa ekstrak kulit manggis memiliki kandungan total fenolik $140 \mathrm{mg}$ dan mempunyai aktivitas antioksidan yang besar. Hal ini berarti pemberian $15 \%$ tepung kulit manggis mempunyai kandungan fenolik sebesar $21 \mathrm{mg}$ dibandingkan dengan kandungan fenolik pada dedak padi yang diberi 5 dan $10 \%$ tepung kulit manggis masing-masing $7 \mathrm{mg}$ dan $14 \mathrm{mg}$. Dengan demikian pemberian $15 \%$ tepung kulit manggis mampu menghambat atau menekan oksidasi lipid.

Penyimpanan dedak padi dengan menggunakan tepung kulit manggis pada taraf yang berbeda dan disimpan selama satu bulan menghasilkan kadar protein kasar yang secara numerik tidak jauh berbeda. Demikian pula secara statistik tidak signifikan pengaruhnya terhadap kadar protein kasar dedak padi $(\mathrm{P}>0,05)$. Walaupun terlihat pada DKM1 terjadi penurunan kadar protein $0,62 \%$. Namun nilai penurunan ini sangatlah tidak berarti atau rendah. Hasil penelitian Ralahalu dkk. (2018) juga memperlihatkan hasil yang tidak signifikan pada kadar protein kasar ransum babi komersial yang disimpan selama satu bulan. Menurunnya kadar protein akan nyata terlihat 
dengan semakin lama penyimpanan. Pernyataan ini berturut-turut didukung oleh penelitian Tambunan, (2002) pada penyimpanan ransum ayam broiler starter selama tiga bulan dan pada penyimpanan ransum babi komersial selama dua bulan.

Kadar bilangan peroksida dedak padi yang disimpan selama satu bulan menggunakan tepung kulit manggis pada taraf yang berbeda menunjukkan hasil yang signifikan $(\mathrm{P}<0,05)$. Penggunaan tepung kulit manggis terhadap kadar bilangan peroksida dedak padi dapat dilihat pada Tabel 5. Kadar bilangan peroksida pada pemberian tepung kulit manggis yang berbeda memperlihatkan hasil yang fluktuatif. Terjadinya penurunan angka bilangan peroksida dedak padi selama satu bulan disebabkan terjadinya degradasi kadar peroksida lebih cepat dibandingkan dengan pembentukannya. Menurut Widodo dkk. (2020), bahwa laju pembentukan peroksida baru lebih kecil dibandingkan dengan laju degradasinya menjadi senyawa lain, mengingat kadar peroksida cepat mengalami degradasi dan bereaksi dengan zat lain. Selain itu terjadinya penurunan angka peroksida juga disebabkan adanya pemberian tepung kulit manggis dalam perlakuan. Kondisi ini diperkuat dengan angka bilangan peroksida pada DKM0 yang lebih tinggi karena disimpan tanpa menggunakan tepung kulit manggis. Hal ini didukung oleh Marlina dan Ratnawati (2015) bahwa antioksidan dalam tepung kulit manggis mampu memperlambat terjadinya reaksi oksidasi yang menghasilkan senyawa peroksida, asam lemak, aldehida dan keton penyebab ketengikan.

\section{SIMPULAN}

Berdasarkan hasil penelitian dapat disimpulkan bahwa penggunaan tepung kulit manggis taraf $5 \%$ dapat menurunkan angka bilangan peroksida dedak padi sampai mencapai angka 7,95 meq/kg, sedangkan penggunaan tepung kulit manggis pada taraf $10 \%$ dapat menekan aroma atau bau dedak padi sampai menjadi agak tengik. Penggunaan tepung kulit manggis jika dinaikan tarafnya sampai $15 \%$ memberikan hasil yang tidak signifikan terhadap warna, kadar air, protein, lemak dan bilangan peroksida dedak padi.

\section{DAFTAR PUSTAKA}

Astawan, M., \& A. E. Febrinda. 2010. Potensi Dedak dan Bekatul Beras Sebagai Ingredient Pangan dan Produk Pangan Fungsional. Jurnal Pangan. 19(1): 14-21.

Dungir, S. G., D. G. Katja, \& V. S. Kamu. 2012. Aktivitas Antioksidan Ekstrak Fenolik dari Kulit Buah Manggis (Garcinia mangostana L.). Jurnal MIPA Unsrat Online. 1(1): 11-15.

Gaspersz, V. 1995. Teknik Analisis Dalam Penelitian Percobaan. Bandung: Penerbit Tarsito.
Herodian, S. 2007. Peluang dan tantangan Industri Berbasis Hasil Samping Pengolahan Padi. Jurnal Pangan. 48(16): 38-49.

Ketaren. 2008. Pengantar Teknologi Minyak dan Lemak Pangan. Cetakan Pertama. Jakarta: Universitas Indonesia Press.

Marlina, L., \& Ratnawati. 2015. Pengaruh Penambahan Ekstrak Kulit manggis Terhadap Ketahanan Oksidasi Minyak Goreng Curah. Jurnal Iptek. 1(1): 34 - 38.

Mulijanti, S.L., S. Tedy, \& Nurnayetti. 2014. Pemanfaatan Dedak Padi dan Jerami Fermentasi pada Usaha Penggemukan Sapi Potong di Jawa Barat. Jurnal Peternakan Indonesia 16(3):179187.

Nurfitriani, S. 2014. Laporan Aspek HPT-Hama Gudang. https://www.academia.edu/7293856/ Laporan aspek hpt_hama_gudang? auto= download. [18/08/2020].

Nakatani, K., N. Nakahata, T. Arawaka, H. Yasuda, \& Y. Ohizumi. 2002 Inhibition of Cyclooxygenesa and Prostaglandin E2Syinthesis by GammaMangostin, a Xanthone Derivative in Mangosteen, in C6 Rat Glioma Cell. Department of Pharmaceutical Moleculer Biology, Tohoku University. Biochem. Pharmacol.

Prasetyo. 2006. Kandungan gizi Pollard dan dedak padi. Blog Agribisnis dan Info Populer. [18/08/2020].

Puspitasari, A. D., Yunianto, \& E. Supriyatna. 2016. Aktivitas antioksidan suplemen Herbal daun sirsak dan manggis. Jurnal Pangan dan Agroindustri. 14(1): 283-290.

Ralahalu, T. N., S. Fredriksz, \& Kadir. 2018. Kualitas Ransum Komersial Babi yang Disimpan pada Beberapa Lama Penyimpanan. Agrinimal Jurnal Ilmu Ternak dan Tanaman. 6(1): 18 25.

Ramahariah, M., F. Fathu, \& Liman. Identifikasi Kualitas Dedak yang Disimpam dalam Berbagai Jenis Kemasan. http://media.neliti.com. [18/08/2020].

Retnani, Y., W. Widiarti, I. Amiroh, L. Herawati, \& K. B. Satoto. 2008. Daya Simpan dan Palatabilitas Wafer Ransum Komplit Pucuk dan Ampas Tebu untuk Sapi Pedet. Prosiding Media Peternakan. Hal. 130- 136.

Rohdiana, D. 2001. Aktivitas Daya Tangkap Radikal Polifenol dalam Daun Teh. Majalah Jurnal Indonesia. 12: 53-58.

Roza, I., Evawati, R. A. Fadri, \& Gusmalini. 2017. Total Fenol Dan Aktivitas Antioksidan Bubuk Kulit Manggis (Garcinia mangostana L.) Dari Buah Segar Dengan Variasi Lama Penyimpanan 
Yang Diolah Secara Mekanis. Jurnal Teknologi Pertanian Andalas. 21(2): 110-116.

Syahputra, P. 2015. Kulit buah manggis (Garciana Mangostana L) sebagai Biolarvasida dalam Menghambat pertumbuhan Nyamuk Demam Berdarah. [Makalah Seminar]. Padang: Jurusan Kimia, Fakultas Matematika dan Ilmu Pengetahuan Alam, Universitas Negeri Padang.

Tambunan, E. E. N. 2002. Pengaruh lama penyimpanan ransum komersial ayam broiler starter bentuk crumble terhadap beberapa sifat fisik dan kandungan protein kasar. [Skripsi]. Bogor: Jurusan Ilmu Nutrisi dan Makanan Ternak, Fakultas Peternakan, Institut Pertanian Bogor.

Wibawa, A.A.P., I W Wirawan, \& I. B. G Partama. 2015. Peningkatan Nilai Nutrisi Dedak Padi Sebagai Pakan Itik Melalui Biofermentasi Dengan Khamir. Majalah Ilmiah Peternakan. 18(1): 11-16.
Widodo, H., L. Adhani, Solihatun, M. Prastya, \& A. Annisa. 2020. Pemanfaatan Minyak Cengkeh Sebagai Antioksidan Alami Untuk Menurunkan Bilangan Peroksida Pada Produk Minyak Goreng. Jurnal Penelitian Dan Karya Ilmiah Lembaga Penelitian Universitas Trisakti. 5(1): 77-90.

Winarno, F.G. 1997. Kimia Pangan dan Gizi. Jakarta: Gramedia Pustaka Utama.

Yokotsuka, T. 1986. Soy Sauce Biochemistry. Adv. Food. Res. (30): 195-329.

Zulbardi, M., A. A. Karto, U. Kusnadi, \& A. Thalib. 2001. Pemanfaatan Jerami Padi Bagi Usaha Pemeliharaan Sapi di Daerah Irigasi Tanaman Padi. Prosiding Seminar Nasional Teknologi Peternakan dan Veteriner. Puslitbang Peternakan Departemen Pertanian Bogor. Hal.256-261.

Available online at journal homepage: http://ojs3.unpatti.ac.id/index.php/agrinimal 